\section{SOI: 1.1 /TAS DOI: $10.15863 /$ TAS International Scientific Journal Theoretical \& Applied Science}

\author{
p-ISSN: 2308-4944 (print) e-ISSN: 2409-0085 (online) \\ Year: 2017 Issue: 12 Volume: 56
}

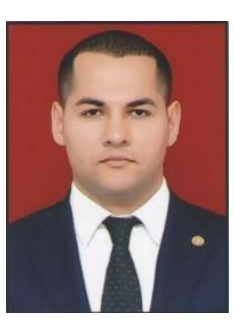

Published: $30.12 .2017 \quad$ http://T-Science.org
Israfil Gasim Abdullayev Senior Foreign Policy Specialist, Bachelor Degree in International Relations and Politics from Keele

University in UK and Master

Degree in Politics, Security and Integration from the University College London

SECTION 22. Policy. Innovations. Theory, practice and methods.

\title{
THE POWER OF SMALL STATES: AZERBAIJAN AND PIPELINE POLITICS
}

Abstract: The article examines the problems and development of reliable transportation of Azerbaijani oil and gas to Turkey and the countries of the European Union. The efficiency and importance of transport communications and pipelines for the delivery of energy resources by the end user is analyzed. The effective influence of oil and gas transportation projects from Azerbaijan on strengthening the energy security of Europe and expanding economic cooperation between the countries are disclosed. A number of proposals on the urgent issue of ensuring the reliability of international pipeline routes for the transportation of oil and gas are given.

Key words: Azerbaijan, pipeline politics, TANAP, TAP, efficiency of international pipeline routes

Language: English

Citation: Abdullayev IG (2017) THE POWER OF SMALL STATES: AZERBAIJAN AND PIPELINE POLITICS. ISJ Theoretical \& Applied Science, 12 (56): 146-150.

Soi: http://s-o-i.org/1.1/TAS-12-56-23 Doi: crossef https://dx.doi.org/10.15863/TAS.2017.12.56.23

\section{Introduction}

The collapse of the long awaited Nabucco gas pipeline project, aiming at transferring Azerbaijani natural gas to Europe, proves how small states, considered weak in traditional international relations discourse, can influence the geopolitics of energy in the region. In the dispute, Azerbaijan used its energy policy to attain strategic and foreign policy goals. In this respect, it played an important role in realization of regional energy projects. Usually the big players decide the fate of big transnational energy projects. Yet, as an independent oil and gas supplier in the South Caucasus, Azerbaijan had a crucial say on decision-making in terms of choosing the countries through which the natural gas would be transported to Europe. Taking into consideration regional geopolitics and its own national interest combined with the lack of real support on the part of the European Union, Azerbaijan preferred to give its full support to the projects of Trans-Anatolian gas Pipeline (TANAP) and the Trans-Adriatic gas Pipeline (TAP).

This article intends to shed light on Azerbaijan's active role in these two natural gas projects that are important parts of the Southern Gas Corridor. This article starts with a short review of the literature on the role of small states in international relations, setting the scene for an analysis of Azerbaijan in decision making for the regional projects of Nabucco/Nabucco West, TANAP and TAP. Then it briefly discusses these projects, and then proceeds to explain how Azerbaijan influenced the realization of TAP and TANAP projects instead of Nabucco/Nabucco West.

\section{The Importance of Small States in International Relations}

Small states have traditionally been seen as weak in the international system. However, this is far from true. Small states often can play a disproportionate role leveraging several aspects of their power in the international system (Ingebritsen, 2006).In fact, by carefully balancing its interests and playing on differences Azerbaijan has been able to influence geopolitical strategy far more than it should have been able to.

However, there has not been much research on the subject (Neumann, 2004). This is a reflection of the fact that during the Cold War, small states were seen as weak players, and de facto allied to one or the other superpower, despite claims to the contrary. However, today scholars have called for a renewed scrutiny of small states as they have increasing importance. Among the reasons are that the world is governed through institutions such as the UN where small states can play a major role, the world is no longer bi-polar, and that institutions and policies must be seen not only as the outcome of great-power 


\begin{tabular}{|c|c|c|c|c|c|c|}
\hline Impact Factor: & $\begin{array}{l}\text { ISRA (India) } \\
\text { ISI (Dubai, UAE } \\
\text { GIF (Australia) } \\
\text { JIF }\end{array}$ & $\begin{array}{l}=1.344 \\
=0.829 \\
=0.564 \\
=1.500\end{array}$ & $\begin{array}{l}\text { SIS (USA) } \\
\text { PИНЦ (Russia) } \\
\text { ESJI (KZ) } \\
\text { SJIF (Morocco) }\end{array}$ & $\begin{array}{l}=0.912 \\
=0.207 \\
=4.102 \\
=2.031\end{array}$ & $\begin{array}{l}\text { ICV (Poland) } \\
\text { PIF (India) } \\
\text { IBI (India) }\end{array}$ & $\begin{array}{l}=6.630 \\
=1.940 \\
=4.260\end{array}$ \\
\hline
\end{tabular}

bargains, but also in terms of the actors' relations (Neumann, 2004).

Reflecting the hitherto neglect of small states in the international system, a lot of literature goes back to the pre-1914 world, following the Great Game theory that sought to explain conflicting Russian and British interests, especially in Asia, in the 19th century (Sergeev, 2014) The original Great Game, whose primary aim was the control of territory, is significant because it introduced the term "geo politics" into political discourse. The British geographer Harold Mackinder was trying to explain a world where Europe had no new places to conquer. $\mathrm{He}$ contended that sea and land powers would therefore clash, and the winner would dominate the world (Mackinder, 1904).

Mackinder, however, wrote in a world where war was accepted as a means of policy, before the carnage of the two world wars, and the game changer---nuclear power. Today most of the core concepts of geopolitics, including "relative gains" and the balance of power itself, that Mckinder held to be important are irrelevant for the states at the upper levels of the system (Fettweis, 2003). However, one aspect of Mckinder's world has remained constant. Though control over territory is no longer the prime motive, competition over resources and resource rich countries is still a constant in world politics.

This is where "small states," meaning countries that have little power in the international state system, have an advantage. Azerbaijan, a former Soviet Republic in the Caucasus, fits this definition. In describing states such as these words like 'weak', 'small', and 'insecure' are used interchangeably
(Payne, 1987). From the perspective of the Oil and Gas industry these terms are applicable to Azerbaijan. This is particularly true in international pipeline negotiations where Azerbaijan can use its geographical position to advantage.

\section{The Southern Gas Corridor as an EU Community priority project}

A decision by the EU Parliament and the Council, dated September 2006, codes the Southern Gas Corridor as "NG3" (gas pipelines from Caspian Basin and Middle East to Europe). Moreover, in its energy strategy the EU Commission classified the Southern Gas Corridor as a Community priority project (Meister\&Viëtor, 2011). The reason for such importance being ascribed to the Southern Gas Corridor is mainly due to gas transit crisis between Russia and Ukraine in 2006 (McDowell, 4 October 2011; Kovacevic, March 2009). As a result, in 2008, the EU Commission accepted the "second strategic energy review - An EU energy security and solidarity action plan" (European Commission, 13 November 2008) which envisaged the diversification of EU's gas supplies through the Southern Gas Corridor. EU members were asked to name the gas projects that they would support.

Thus, the proposed projects for the Southern Gas Corridor became to include energy projects starting from the Caspian Basin and the Middle East; namely, Nabucco (later on reduced to the Western Nabucco) gas pipeline, TANAP, TAP, the Interconnector Turkey-Greece-Italy, and the Azerbaijan-Georgia-Romania Interconnector.

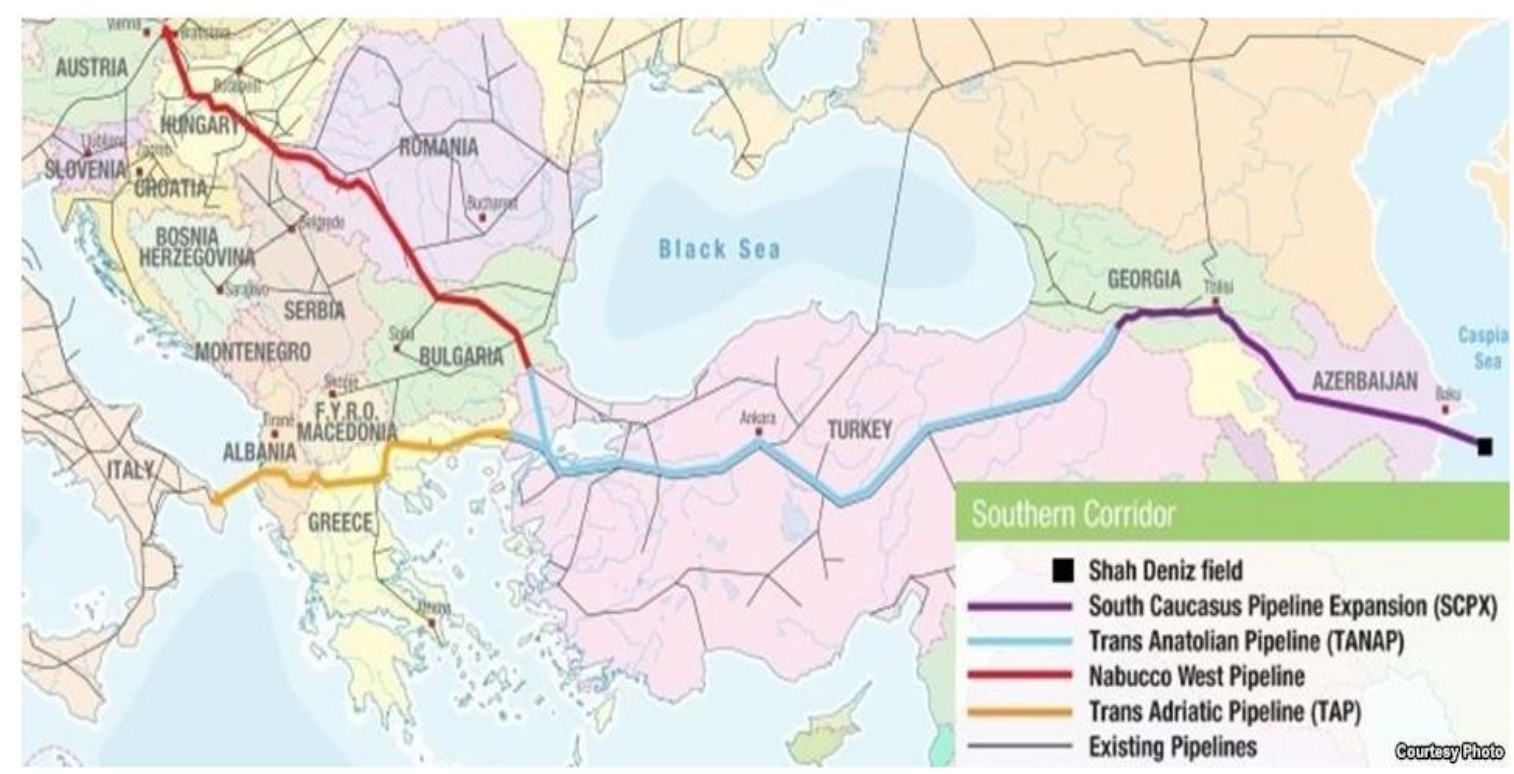

Figure 1 - Map of the Southern Gas Corridor. Source: Recknagel, C. (27 June 2013). RFERL.

ISPC Generalization of scientific results, 
The EU has shown an interest in realization of these projects to diversify its energy supply sources. Yet, different EU members have shown varying degrees of support for these projects taking into account their own degree of dependence on foreign energy sources. For example, countries like Bulgaria, Romania, Hungary and Austria on the one hand supported the Nabucco pipeline, and on the other hand, also expressed their interest in the rival South Stream project $^{1}$, which was supposed to transfer Russian gas through the Black Sea to Bulgaria. This in return played an important role in the realization or dismissal of projects such as TANAP/TAP and Nabucco. However, it would be short-sighted to overlook the role of energy supplier countries in the decision-making process of energy projects.

\section{The Nabucco project}

The Nabucco gas pipeline project was the main route that was politically supported by the EU and the U.S. It was first discussed in 2002 and aimed at transferring natural gas from the South Caucasus, Turkmenistan and, under changed conditionsalso from Iran to Europe (Mitschek, December 2011; Hafner, 28 March 2015). The 3,800-km pipeline, from Central Asia to Europe passing through Azerbaijan, Turkey and South Europe, was estimated to cost around $\$ 8$ billion. The Nabucco consortium included six companies - BOTAS (Turkey), Bulgarian Energy Holding (Bulgaria), Transgaz (Romania), MOL (Hungary), OMV (Austria) and RWE (Germany) - with equal stakes (Mitschek, December 2011).

The prolonged negotiations over the realization of the project, its direct competition with the South Stream and other smaller projects such as the TANAP, finally led to the abandonment of the Nabucco project in 2013. It should be noted that the $3,800-\mathrm{km}$ project was first reduced to $1,300-\mathrm{km}$ as the part from Azerbaijan up to the Bulgarian border was taken over by the TANAP project. The remaining part became known as Western Nabucco andwas supposed to transfer natural gas from Turkey to Austria. This was also abandoned in June 2013 as Azerbaijan decided to go for the TAP option to transfer the gas via Greece and Albania and under the Adriatic Sea to Italy (Weiss, 13 July 2013). The decisiveness of Azerbaijani and Turkish governments and their financial commitment to the TANAP and TAP projects were a crucial factor in the dismissal of Nabucco project.

At the Southern Gas Corridor forum held in Baku in May 2013, vice-President of the State Oil Company of Azerbaijan Republic (SOCAR), Mr. Elshad Nasirov complained that "Europeans and

${ }^{1}$ The South Stream project was abandoned in late 2014. See Gotev, G. (10 December 2014).
Americans could easily have financed the Nabucco project a few years ago, at a cost equivalent to that of a few weeks of military operations in Iraq for example" (Socor, 30 May 2013). In an interview in February 2013, Mr. Nasirov said that "if the EU has not found the means to implement this project, we would not argue with the opinion of the EU about how the interests of European countries are protected. We will not argue with the EU, but we can confirm the fact of inability of the EU and member countries to find ways to build a pipeline" (ABC.az, 12 February 2013). That shows that the Azerbaijani government, mainly represented by SOCAR for energy projects, was already dissatisfied with the Nabucco project and took an indifferent stance to its realization. Instead it supported the alternative projects that were already announced; namely, such as TANAP and TAP.

\section{TANAP and TAP gas pipeline projects}

Amidst the negotiations and Production Support Agreements (PSAs) on Nabucco project, Azerbaijan and Turkey announced their plan to launch the 1850$\mathrm{km}$ TANAP project to transfer gas from the Caspian Sea through Turkey to Greece. SOCAR expressed its full support for TANAP mainly on the basis of argument that it costs far less, 5 billion EUR, when compared to Nabucco (Rowley, 2009).

As Nabucco's dismissal was announced, Azerbaijan and Turkey showed their full commitment towards launching the TANAP project. Construction began in early 2015, and the project is planned to be completed by 2020 . Initially $16 \mathrm{bcm}(6$ bcm will be pumped into Turkish gas network) natural gas is going to be transported, and in a later stage this is planned to be extended to $24 \mathrm{bcm}$ and then to $31 \mathrm{bcm}$ (TANAP, not defined:7). TANAP will be the main part of the Southern Gas Corridor running from Azerbaijan to the Turkish-Greek border. By 2013, the European part of the Corridor was to be decided between Nabucco-West and TAP, and as already have been touched upon, TAP was favored by the Shah-Deniz II consortium ${ }^{2}$ in Azerbaijan. With a length of $878-\mathrm{km}$, TAP had an advantage over Nabucco-West as it was $500-\mathrm{km}$ shorter.

Another advantage is that, in the future its capacity can be expanded from $10 \mathrm{bcm}$ to $20 \mathrm{bcm}$ with additional compressors and it can be connected to other existing and planned pipelines to transport gas to the South-Eastern, Central as well as Western Europe (Trans Adriatic Pipeline, not defined). Yet, Nabucco-West had other advantages, that are listed

\footnotetext{
${ }^{2} \mathrm{~A}$ consortium led by BP and South Caucasus Pipeline Company to develop gas production from Shah Deniz field, which is the biggest natural gas field in Azerbaijan. See Reuters (26 May 2014).
} 
by the Mr. NatiqAliyev, who was then the Minister for Industry and Energy of Azerbaijan, "I consider that Nabucco West is the best option from all points of view because it is a project of the European Union and they always supported this project. It has a big capacity, big diameter, and it gives us the opportunity to deliver gas to east and central Europe. It's a more reliable market for Azeri gas." (Reuters 24 July 2012). In 2013 TAP was chosen to complete the European leg of the EU's Southern Gas Corridor, and the Nabucco project officially was cancelled.

\section{Nabucco to TANAP and TAP: Azerbaijani national interest versus $\mathrm{EU}$ indecisiveness?}

Though Azerbaijan showed its interest in the realization of the Nabucco project to transfer its natural gas resources to Europe, it has played a crucial role in the realization of the TANAP and the TAP projects. The Nabucco project was a joint EU endeavor, but TANAP and TAP were mainly driven by Azerbaijan and Turkey.

Energy projects in the region are closely associated with geopolitics. In this respect, calculating its long-term political and economic benefits, the Azerbaijan did not passionately support the Nabucco project as it was in direct competition with the Russian South Stream Project. Pursuing a multi-vector foreign policy - good relations with all powerful neighbors, the US and the EU -Azerbaijan also took into consideration Russia's possible reactions. However, TANAP and TAP are not projects in the same league as Nabucco so as to challenge the natural gas market that was mainly targeted by the South Stream.In 2010, referring to Nabucco, President Ilham Aliyev said that the project is "too politicized" and also complained about the lack of leadership on the side of the EU (News.az, 28 January 2010).

Moreover, TANAP and TAP are sufficient to transport Azeri gas into Europe; that is the minimal national interest Azerbaijan has to ensure in terms of its energy policy. Yet, Azerbaijan can transport more than its own gas given the fact that capacity of both projects is planned to be expanded gradually.

Furthermore, from the start, Azerbaijan kept various options open. TANAP and TAP, were already on the table while negotiations over Nabucco was going. That provided the Azerbaijani government with a golden opportunity to assess the costs and benefits of each energy project that were at hand. Azerbaijan's position for the choice of pipelines for Southern Gas Corridor is summed up by the President Ilham Aliyev during the meeting with Bulgarian Prime Minister Boyko Boryssov in March 2015: "We think that we can unite TAP and Nabucco. It is not important what you call this route. Our main goal is that the volumes of Azeri gas enter Europe...the more EU countries receive our gas, the better for all." (Gotev, 5 March 2015).

However, commercial interests cannot be overlooked. For instance, TAP prevailed over Nabucco West in terms of being less costly. And, TAP mainly targets Italian market which is exempt from tense market competition in comparison to the market targeted by Nabucco West, namely Austria where energy infrastructure and networks are better developed which can draw down the prices (Pantazi, 1 July 2013). In an end effect, that is not fulfilling EU's best interest in terms of energy security as TAP is not targeting the countries, which are mostly depended on Gazprom's gas, as Nabucco West would have done.

Pursuing its policy of diversification of energy transportation, Azerbaijan has accomplished much with gaining ownership in transport routes such as in TANAP. In other words, Azerbaijan is not an ordinary participant of the project, rather a leading one with a solid commitment both financially and politically. Being a small state, with its limited capacity, Azerbaijan preferred to take a leading role in relatively smaller project, rather than being a small partner in a big one. Put it differently, instead of being a pawn in a great game, Azerbaijan uses its energy resources and geo-strategic location to attain more power and to support the projects that serves its national interests better.

\section{Conclusion}

To sum up, dismissal of the Nabucco is not a failure for Azerbaijan, taking into consideration problematic geopolitics of the region, Azerbaijan has secured the best it could do. Market for its promising natural gas resources is secured, a possible hassle with Russia was avoided, and it has captured a leading role in the Southern Gas Corridor. However, that is not to argue that, Nabucco could not bring greater benefits for the country; it could have granted Azerbaijan more geopolitical importance. Azerbaijan could take such an offer only with the strong backing and commitment of the EU and US, as the case of Baku-Tbilisi-Ceyhan oil pipeline project proved.

\section{References:}

1. ABC.az. (12 February 2013) SOCAR: Azerbaijan not sure of Nabucco West 
realization.

Available:

http://abc.az/eng/news_12_02_2013_71625.htm 1, Accessed on 28 November 2017.

2. European Commission. (13 November 2008) Second Strategic Energy Review AN EU ENERGY SECURITY AND SOLIDARITY ACTION PLAN. 781 Final. From http://eurlex.europa.eu/LexUriServ/LexUriServ.do?uri= COM:2008:0781:FIN:EN:PDF, (Accessed: 29 November 2017).

3. Fettweis C. (2003) Revisiting Mackinder and Angell: The obsolescence of great power geopolitics. Comparative Strategy, 22(2), 109129.

4. Gotev G. (5 March 2015) Bulgaria wants to revive Nabucco, Azerbaijan says pipeline name 'not important'. Euractiv. Available: http://www.euractiv.com/section/energy/news/b ulgaria-wants-to-revive-nabucco-azerbaijansays-pipeline-name-not-important/ (Accessed: 2 December 2017).

5. Gotev G. (10 December 2014) Russia confirms decision to abandon South Stream. Euractiv. Available:

http://www.euractiv.com/section/energy/news/r ussia-confirms-decision-to-abandon-southstream/, (Accessed: 1 December 2017).

6. Hafner M. (28 March 2015) THE SOUTHERN GAS CORRIDOR AND THE EU GAS SECURITY OF SUPPLY: WHAT'S NEXT? Natural Gas World. Available: https://www.naturalgasworld.com/southern-gascorridor-and-eu-gas-security-of-supply-22688, Accessed on 1 December 2017.

7. Ingebritsen C. (2006) Small States in International Relations. University of Washington Press.

8. Kovacevic A. (March 2009) The impact of the Russia-Ukraine gas crisis in South Eastern Europe. Oxford Institute for Energy Studies.

9. Mackinder H.J. (1904) The geographical pivot of history. Royal Geographical Society.

10. Meister S., Viëtor M. (2011) The Southern gas corridor and the south Caucasus. South Caucasus-20 Years of Independence. Berlin: Friedrich Ebert Stiftung.

11. McDowell D. (4 October 2011) In UkraineRussia Gas Dispute, Kiev Runs Out of Leverage. World Politics Review. Available: https://www.worldpoliticsreview.com/articles/1 0217/in-ukraine-russia-gas-dispute-kiev-runsout-of-leverage, (Accessed: 2 December 2017).

12. Mitschek R. (December 2011) Nabucco: A pioneering pipeline project. $20^{\text {th }}$ World Petroleum Congress. Available: http://www.worldpetroleum.org/docs/docs/20th/WPCconfull.pdf, (Accessed: 2 December 2017).
13. Neumann I. B. (2004) Lilliputians in Gulliver's World?: small states in international relations.

14. News.az. (28 January 2010) Nabucco pipeline project lacks leadership. Available: https://news.az/articles/economy/7766, (Accessed: 2 December 2017).

15. Pantazi C. (1 July 2013) HotNews Interview with the European Commissioner for Energy Gunther Oettinger. Available: http://m.hotnews.ro/stire/15104603, (Accessed: 2 December 2017).

16. Payne A. (1987) Politics, security, and development in small states. Taylor \& Francis.

17. Recknagel C. (27 June 2013) RFERL. Available:

http://www.rferl.org/content/nabucco-gaspipeline-rivals-future-in-doubt/25030223.html, (Accessed: 30 November 2017).

18. Reuters. (26 May 2014) BP-led consortium awards \$735 million contract for Shah Deniz gas project. Available: https://uk.reuters.com/article/uk-azerbaijanbp/bp-led-consortium-awards-735-millioncontract-for-shah-deniz-gas-projectidUKKBN0E619X20140526, (Accessed: 4 December 2017).

19. Reuters. (24 July 2012) Azeri energy minister backs Nabucco West gas pipeline. Available: https://www.reuters.com/article/azerinabucco/azeri-energy-minister-backs-nabuccowest-gas-pipeline-idUSB5E8IH01020120724, (Accessed: 3 December 2017).

20. Rowley M. (2009) The Nabucco Pipeline Project-Gas Bridge to Europe. Pipeline and Gas Journal, 236(9), 72-73.

21. Sergeev E. J. (2014) The great game, 1856 1907: Russo-British relations in Central and East Asia. Washington, DC: Woodrow Wilson Center Press.

22. Socor V. (30 May 2013) Comparative Advantages of Nabucco-West Offset by Lack of Financing.Eurasia Daily Monitor. Volume: 10 (102). Available: http://www.jamestown.org/single/?tx ttnews\%5 Btt_news\%5D=40958\&no_cache=1\#.VU0Fi46 qqko, (Accessed: 2 December 2017).

23. TANAP. (2017) Trans-Anatolian Natural Gas Pipeline. Available: http://www.tanap.com/content/file/whytanap_fo r_web_EN.pdf, (Accessed: 4 December 2017).

24. Trans Adriatic Pipeline. (2017). TAP at a glance. Available: https://www.tap-ag.com/thepipeline, (Accessed: 4 December 2017).

25. Weiss C. (13 July 2013) European Union's Nabucco pipeline project aborted. WSWS. Available: https://www.wsws.org/en/articles/2013/07/13/n abu-j13.html, (Accessed: 4 December 2017). 